ISSN:2528-9527

E-ISSN : 2528-9535

YIl Year: 8

Cilt Volume: 8

Sayı Issue : 14

\title{
Okul Öncesi Dönem Çocukların Ahlaki ve Sosyal Kural Bilgilerinin İncelenmesi ${ }^{1}$
}

\author{
DOI: $10.26466 /$ opus.378956
}

\author{
Ayșe Meriç $^{*}$-Arzu Özyürek ${ }^{* *}$ \\ * Öğr. Gör., Ordu Üniversitesi Fatsa MYO. Çocuk Gelişimi Bölümü, Fatsa/Ordu/Türkiye \\ E-Posta: aysemeric@odu.edu.tr \\ ORCID:0000-0003-4124-6528 \\ ${ }^{* *}$ Doç. Dr., Karabük Üniversitesi Sağlık Bilimleri Fakültesi Çocuk Gelişimi Bölümü, \\ Karabük/Türkiye \\ E-Posta: a.ozyurek@karabuk.edu.tr \\ ORCID:0000-0002-3083-7202
}

Öz

Okul öncesi yıllar, diğger gelişim alanlarında olduğu gibi ahlaki ve sosyal gelişim için de kritik bir öneme sahiptir. Çocuklar bu dönemde, bir yandan biliş ve dil alanlarında gelişme gösterirken bir yandan da ahlaki ve sosyal davranış özelliklerini geliştirirler. Bu çalışmada, okul öncesi dönem çocukların ahlaki ve sosyal kural bilgi düzeylerinin çeşitli değiş̧kenler açısından incelenmesi amaçlanmıştır. Çalışma grubunu, okul öncesi eğitim kurumuna devam eden 123'ü kız, 104'ü erkek olmak üzere 227 çocuk oluşturmuştur. Araştırmada çocukların ahlaki ve sosyal kural bilgilerinin değerlendirilmesinde Smetana (1981) tarafindan geliştirilen, Seçer ve Sarı (2006) tarafindan Türk kültürüne uyarlanan "Ahlaki ve Sosyal Kural Algısı Ölçeği" (Preschool Children's Conceptions of Moral and Social Rules) kullanılmıştır. Elde edilen veriler, bilgisayar ortamında SPSS 20 paket programı kullanılarak analiz edilmiştir. Sonuç olarak; Çocukların ahlaki ve sosyal kural bilgilerinin cinsiyet değişkenine göre farklılaşmadığı, babalar üniversite mezunu ve profesyonel bir meslek grubunda çalışan çocukların, sosyal kural bilgilerinin diğerlerine göre daha iyi düzeyde olduğu saptanmıştır. Okul öncesi çocuklarm ahlaki kural bilgi düzeyleri ile sosyal kural bilgi düzeyleri arasında pozitif yönlü bir korelasyon olduğu saptanmıştır. Elde edilen bulgular, alan yazınla desteklenerek tartışılmıştır.

Anahtar Kelimeler: Okul Öncesi Dönem, Ahlaki Kural, Sosyal Kural.

\footnotetext{
${ }^{1}$ Bu çalışma, Doç. Dr. Arzu Özyürek danışmanlığında Ayşe Meriç tarafından hazırlanan yüksek lisans tez çalışmasından türetilmiştir.
}

OPUS @ Uluslararası Toplum Araştırmaları Dergisi-International Journal of Society Researches ISSN:2528-9527 E-ISSN : 2528-9535

http://opusjournal.net 
ISSN:2528-9527

E-ISSN : 2528-9535

YIl Year: 8

Cilt Volume: 8

Sayı Issue :14

Uluslararası Toplum Araştırmaları Dergisi International Journal of Society Researches

Nisan April 2018

Makalenin Geliş TarihiReceived Date: 15/01/2018

Makalenin Kabul Tarihi Accepted Date: 04/04/2018

\title{
A Study on Pre-School Children's Knowledge of Moral and Social Rules
}

\begin{abstract}
Pre-school years have a considerable significance for the moral and social development as in other areas of development. In this period, children develop their cognitive and language skills, as well as their moral and social behavioral characteristics. This study aims to examine preschool children's knowledge of moral and social rules with respect to certain variables. The study group consisted of a total of 227 children, of whom 123 were girls and 104 were boys, attending a preschool education institution.In the reseach, to evaluate the children's moral and social knowledge, a scale "Preschool Children's Conceptions of Moral and Social Rules" developed by Smenta (1981) and adapted to Turkish culture by Seçer and Sarn (2006) was used. The obtained data were analyzed by SPSS 20 packet program. The results showed that children's knowledge on moral and social rules didn't vary with respect to their gender. The children whose fathers are university graduates and have a professional job have considerable knowledge of social rules when compared to the others. A positive correlation was found between pre-school children's knowledge on moral and social rules. Obtained findings were discussedwith supporting field literature.
\end{abstract}

Keywords: Pre-School Period, Moral Rules, Social Rule,

OPUS @ Uluslararası Toplum Araştırmaları Dergisi-International Journal of Society Researches ISSN:2528-9527 E-ISSN : 2528-9535

http://opusjournal.net 


\section{Giriş}

Toplumu toplum yapan kurallardan biri ahlaki kurallardir. Ahlaki kuralların öğrenilmesi aile ortamında başlayıp bireyin hayatı boyunca davranışlarını ve çevresiyle uyumunu etkiler.

Ailede başlayıp, okulda ve yaşamın diğer yıllarında da gelişmeye devam eden ahlak eğitimi, aklın ve kalbin birlikte uyum içinde olması durumu olarak tanımlanmaktadır (Uyanık Balat, 2005; Uyanık Balat ve Balaban Dağal, 2009). Okul öncesi yaşlar, bireyin yaşamı boyunca topluma uyumu için gerekli olan sosyal-duygusal beceriler ve bu yeterliklerin oluşması açısından kritik bir öneme sahiptir (Sheridan, Knoche, Edwards, Bovaird ve Kupzyk, 2010). Çocuklar bu dönemde, bir yandan biliş ve dil alanlarında gelişme gösterirken bir yandan da ahlaki ve sosyal davranış özelliklerini geliştirmeyi sürdürmektedirler. Bu nedenle okul öncesi yıllar, diğer gelişim alanlarında olduğu gibi ahlaki ve sosyal gelişim için de kritik bir öneme sahiptir.

Ahlak, kişinin doğru ile yanlışı ayırt edebilmesini sağlayan, kişinin toplum içindeki görev ve sorumluluklarını öğreten ve uygulamasını sağlayan kurallar ve değerlerin tümüdür (Can, 2015). Ahlâk bireyin iyikötü, doğru-yanlış, haklı-haksız durumları bilinçli olarak yorumlayarak buna göre bir davranışta bulunmasını sağlayan bilişsel bir yapıdır (Danovitch ve Keil, 2007; Özgün, 2012; Çiftçi Arıdağ, 2015). Ahlak, toplum içinde bireylerin uymak zorunda oldukları davranış biçimleri ve kurallardır (TDK, 2016). Çocukta ahlak gelişimi denildiğinde akla ilk gelen, toplumsal kurallardır. Çocuğun toplumla uyum içinde yaşaması, doğruyla yanlış kavramlarını kazanabilmesi, hak ve adalet duygusunun yerleşebilmesi, ahlak kurallarına uygun yaşam biçimi ve toplumun değerlerine uygun davranma anlaşılabilir. Ahlak gelişiminde, bireyin toplumsal değer yargılarını öğrenerek içinde bulunduğu çevreye uyum sağlaması, aynı zamanda kendi değer yargıları ve ilkelerini oluşturması amaçlanmaktadır (Tuzcuoğlu, 2014). Ahlak gelişimi, doğduğu andan itibaren çocuğun çevresindekilerle etkileşimiyle başlar ve özellikle iki yaşından itibaren dil kullanımının artmasıyla toplumsal kurallar pekişmeye başlar (Özgün 2012). Ahlak gelişimi, kişilik gelişiminin bir parçasıdır ve çocukların çevrelerindeki sosyal dünyaya uyum sağlaya- 
bilmelerinde gerekli kuralları öğrenmelerini içermektedir (Aydın, 2014; Tuzcuoğlu, 2014).

Ahlak gelişimi, çocuğun adalet algısı, içinde bulunduğu toplumun veya grubun kültürel değerleri, doğru ya da yanlış kavramlarına dair algisı ve ahlaki kurallara dair davranışlarında oluşan değişimler şeklinde tanımlanabilir. Psikanalitik kuram, ahlak gelişimini ele alan ilk kuram olmuştur ve ahlakın çocuğun vicdan gelişimine bağlı olarak geliştiğini ileri sürmektedir. Piaget ise ahlaksal unsurları kavramlara dayandırarak bireyin gelişiminde ahlakı incelemiştir. Freud anne-baba ilişkileri, duygular ve suçluluk konularına değinirken Piaget biliş, adalet ve akran ilişkileri gibi temel konulara değinmiştir (Bee ve Boyd, 2009; Çam, Çavdar, Seydooğulları ve Çok, 2012; Özgün, 2012). Gelişimin önemli bir özelliğini oluşturan ahlaki gelişiminin duygusal, davranışsal ve bilişsel olmak üzere üç temel yönü bulunmaktadır (Gander ve Gardiner, 2007). Psikanalist, sosyal öğrenme ve bilişsel gelişim kuramları, ahlak gelişiminin farklı yönlerini ele almışlardır (Yapıcı ve Yapıc1, 2005; Bee ve Boyd, 2009; Kağıtcıbaşı ve Cemalcılar, 2014). Freud, ahlak ve kişilik gelişimini duygusal ve güdüsel bir süreç olarak ele almıştır ve ahlaki gelişimi, id, ego ve süperego arasındaki denge ilişkilerine bağlamaktadır. Freud'a göre, ahlaki gelişim, kişilik gelişimine paralel olarak, belirli psikoseksüel dönemlerden geçerek gerçekleşmektedir (Bee ve Boyd, 2009; Yapıc1 ve Yapıc1, 2010; Hatunoğlu, Halmatov ve Hatunoğlu, 2012). Freud, ahlak gelişimini temel kimlik yapılarından biri olan süperegonun bir işlevi olarak görmüş ve süperegonun içinde yer alan "vicdan" ahlak gelişiminin sonucu olarak ele almıştır (Turiel, 2002). Erikson ise, ahlaki gelişimin çocukluktan yetişkinliğin ilk dönemlerine kadar devam ettiğini ileri sürmüştür (Can 2015). Ayrıca Erikson, çocukların ahlâk kurallarını hem anne hem de babadan öğrendiğini savunmuştur (Bee ve Boyd, 2009).

Toplumsal öğrenme kuramcıları, çocukların ahlaki davranışlarını etkileyen faktörleri, anne-babaların, otorite figürlerinin, ceza ve kuralların varlığı veya yokluğunun etkilerini araştırmak üzere çalışmalar yapmışlardır (Gander ve Gardiner, 2007; Özgün, 2012). Çocuklar ahlaki eğitimlerini ailede almaya başladıklarından ailenin yapısı, tutumu ve etkileşim biçimi, ahlaki gelişimlerinde önemli bir yer tutmaktadır. İnsanoğlu dünya üzerinde var olduğu sürece ahlaki meziyetlerle ilgili konular ve onla- 
rın davranışlarının nasıl etkilendiği inceleneceği söylenebilir (CoraWaters, 2004). Davranışçı yaklaşıma göre, ahlâki kural bilgisi koşullanma yoluyla edinilir ve otorite figürlerinin kabul ettiği davranışlar birey tarafından yapılmaya devam edilir, kabul etmediği davranışlar yanlış kabul edilir (Topbaşı, 2006). Bilişsel gelişim kuramcıları, çocuklar büyüdükçe ahlaki akıl yürütmelerinin nasıl değiştiği, bu değişimleri hangi faktörlerin etkilediği konusunda çalışmalarda bulunmuşlardır. Bilişsel olarak, insanlar yapılması ya da yapılmaması gereken şeyler hakkında düşünürler. Bireyin akıl yürütmesi, tutumları ve değerleri ile ahlaki gelişiminin bu yönünü bilişsel gelişim desteklemektedir. İnsanlar davranışlarıyla, ahlaki akıl yürütmeleriyle tutarlı veya tutarsız bir biçimde davranabilirler. İnsanların neyin doğru neyin yanlış olduğuyla ilgili bazı duyguları vardır ve bazen duygular, düşünce ve davranışlara uygun olmayabilir (Nisan ve Kohlberg, 1982; Gander ve Gardiner, 2007).

Çocuğun gelişim süreci, ahlâki kurallardan ahlâki olmayan kurallara doğru aşamalı bir ilerleme göstermektedir (Smetana, 1981). Çocuklar iyi ile kötünün ayrımını, doğdukları andan itibaren anne-babaların veya onlara bakan bireylerin emir ve yasaklarından öğrenmektedirler. Dolayısıyla yaşamlarının ilk yıllarında, davranışlarında kendi akıllarının ve kalplerinin bir katkısından söz edilemez. Çocuk büyüdükçe kendi aklından ve kalbinden emir almaya başlar, kendine özgü davranışlar geliştirir. Kendine ve çevresine saygı, sorumluluk, kişilik, erdem gibi duygu ve düşünceler yavaş yavaş oluşurken çocuk iyi ve kötü anlayışını genişletir ve geliştirir. Saygı, paylaşma, doğruluk gibi ahlak kuralları, bütün zaman ve mekânlarda geçerlidir, değişmezdir (Aydın, 2011). Aynı şekilde çocuklar, çevreleriyle etkileşim sayesinde belirli toplumsal kuralları öğrenir ve kendi sosyal kural anlayışlarını geliştirirler (Çeliköz, Seçer, Çetin ve Demir Şen, 2008). Ahlaki kural anlayışları ise, sosyal kural anlayışından daha erken bir zaman diliminde gelişmektedir (Yau ve Smetana, 2003).

Sosyal gelişim, çocukta benliğin oluşmasına yardım eden önemli bir süreçtir (Bee ve Boyd, 2009). Çocuğun yaşantıları sonucu ve çevresindeki kişilerin etkisiyle benlik kavramı oluşmaktadır. Okul öncesi dönemde benlik, genel olarak çocuğun ailesi ve ona bakan diğer kişiler, sonrasında öğretmenlerin çocuğa karşı tutum ve davranışlarından etkilenmektedir. Çocukları disipline etmek adına gerçekleşen olumsuz 
yaklaşımlar, onların benlik kavramı edinimlerine zarar verebilir. Sosyalleşme; sosyal kurallara uygun davranmak olarak tanımlanabilir. Doğuştan getirilen bir yetenek olmayan sosyal kurallara uygun davranma, gelişim süreci içinde anne-baba, kardeşler ve okuldan yani bir başka ifadeyle yakın çevreyle etkileşim yoluyla kazanılmaktadır (Giren, 2008; Orçan, 2012; Aydın, 2014). Çocukların sosyal gelişiminde iki önemli sosyalleşme aracı aile ve akrandır (Smetana, 1999). Çocuk doğduğu andan itibaren, fiziksel ve sosyal çevreye uyumunda anne ve babasından en büyük desteği almaktadır. Sosyalleşme, çocukların toplumun diğer üyelerinin değerlerinden, davranışlarından ve kültüründen etkilenerek, içinde bulunduğu gruba uyum sağlayarak işlevsel bireylere dönüştükleri bir süreçtir (Gander ve Gardiner, 2007; San Bayhan ve Artan, 2007). Çocukların sosyalleşmesi, sosyal uyarıcılara uygun davranabilmesi, içinde bulunduğu kültürdeki diğer insanlarla geçinebilmesi ve onlar gibi davranabilmesidir (Yavuzer, 2015). Okul öncesi dönemde en önemli süreçlerden biri sosyal kuralları öğrenerek sosyalleşmektir. Bu süreç içinde sosyal kurallarla karşılaşan çocuk, etrafındaki insanların da sosyal kurallara uymaları gerektiğini ve sosyal kuralları öğrenmeye başlamaktadır (Akman, 1994). Sosyalleşen birey, yaşadığı toplumun değerlerine ve beklentilerine uygun davranır, gereksinimleri ve istekleri ile toplumun istek ve beklentileri arasında denge kurabilir (Sarıçam ve Halmatov, 2012; Güler, 2015). Çocuğun, toplumun ne anlama geldiğini anlaması ve karşılıklı saygıya dayanan doğru ve yanlış davranışları yargılaması empati yolu ile sağlanmaktadır (Çiftçi, 2003). Başarılı bir sosyalleştirme sonucunda, çocukta iç denetim gelişir, sosyal kurallar ve toplum zorlamasa dahi birey sosyal kurallara uygun davranışlarda bulunur (Aral ve Durualp, 2011).

Çocuğun sosyal olgunluğa ulaşması, başlangıçta anne-babasıyla sağlıklı iletişim kurması, içinde yaşadığı toplumun değerlerini öğrenmesi yoluyla gerçekleşmektedir (Bedard ve Dhuey, 2006; Atay, 2011). Sosyalleşmenin bireyin toplumsal kültürle bütünleşmesini ve içinde yaşadığı toplumla uyum sağlamasını mümkün kılan bir işlevi vardır (Uzamaz, 2000). Toplumlar eğitim sistemlerini belirlerken kültürel değerlerini göz önünde bulundurarak çocukları o değerlere uygun davranışlar gösterecek şekilde yetiştirmeye özen gösterir. Böylece toplumlar çocuk yetiştirme tutumları ile kültürlerini yeni nesillere aktarmaktadırlar 
(Aral ve Durualp, 2011). Sosyal olarak yeterli olan çocuklar, daha karmaşık beceriler geliştirebilir, daha olumlu davranışlar sergiler, annebabaları ile daha olumlu ilişkiler kurabilirler. Sosyal yeterliğin temelinde, bireyin toplum içinde uyumlu, başarılı ilişkiler geliştirerek kendi bireysel hedeflerine ulaşabilmesi de yer almaktadır (Yurtsever Kilıçgün, 2016). Dünyada en fazla bakıma ve korunmaya ihtiyaç duyan canlı insan yavrusudur (Geçtan, 1999). Çocuklar doğdukları andan itibaren kendilerini sosyal bir yaşamın içinde bulurlar ve içinde bulundukları bu sosyal-kültürel ortama uyum sağlamaya çalışırlar. Bu uyum çabası doğumla başlar ve yaşamın ilerleyen yıllarında gelişim göstererek devam eder. Çocukların tüm gelişim alanlarında olduğu gibi sosyal gelişimlerinin temeli de büyük oranda yaşamın ilk yıllarında atılmaktadır (Günindi, 2010; Yapıcı ve Yapıc1, 2010; Yavuzer, 2012). Bu nedenle sosyal becerilerin kazanılmasında, erken çocukluk dönemi yaşamın en önemli dönemini oluşturmaktadır.

Sosyal gelişim, yaşam boyu devam eden bir süreç olup bilişsel ve ahlaki gelişim ile paralellikler göstermektedir. Dolayısıyla bireyin başka insanlarla sağlıklı ilişkiler kurması ve sürdürebilmesi bilişsel ve ahlaki akıl yürütme süreciyle yakından ilgilidir (Aydın, 2014). Toplum içinde uyumun sağlanabilmesi için toplumu oluşturan bireylerin bu kurallar doğrultusunda davranmaları gerekmektedir. Sosyal kurallar günlük sosyal ilişkiler gereği olan, toplum tarafından izin verilen veya izin verilmeyen davranışları açıklayan, sosyal ilişkileri sürdürmeye yönelik, içinde bulunulan ortamlara bağlı değerleri içermektedir. Sosyal kurallar, sosyal sistemin içerisindeki ilişkileri düzenleyen rastgele veya ortaklaşa karar verilmiş uygulamaları ifade etmektedir (Smetana, 1989). Toplumlarda kültürün nesilden nesile devam etmesinde sosyalleşmenin rolü önemlidir. Böylece bir toplum çocuk yetiştirme yolluyla kültürünü sonraki nesillere aktarmaktadır (Yavuzer, 2009; Yapıcı ve Yapıc1, 2010). Sosyal kurallar farklı ortamlarda sosyal etkileşimi düzenleyen dışsal olarak ileri sürülen kurallardır. Gelenekleri içerir ve değiştirilebilir. Bu kuralların ihlal edilmesi, daha çok ilgili yerleşim alanı içinde yanlışlığın oluşup oluşmadığına bağlıdır (Smetana, 2006).

Çocukların sosyal çevre ile ilk bağları genellikle anne-baba ve aile bireyleri aracılığıyla olmaktadır. Bu nedenle aile, çocuğun ilk sosyal deneyimleri yaşadığı önemli bir yerdir (Dinç, 2002; Girgin, Kurnaz ve Zo- 
bu, 2011; Günindi ve Kandır, 2012; Yavuzer, 2015). Çocukların ilk sosyal davranışları, yakın çevrelerinden gördükleri tepkilere göre şekillenmektedir. Sosyal gelişimin, çocukların anne, baba, kardeş, okul ve toplumun diğer üyeleriyle iyi ilişkiler kurmasında, toplum tarafından kabul edilen kurallara uymasında, görev ve sorumluluklarını yerine getirmesinde, çevresi tarafından kabul edilmesinde önemli bir rolü vardır (Ağır, 2014; Aral, Gürsoy ve Köksal, 2001; Gander ve Gardiner, 2007; Yapıcı ve Yapıcı, 2010; Orçan, 2012). Çocukların sağlıklı aile ilişkileri içinde sosyal gelişimlerinin desteklenmesi, ilk ve en önemli sos- yal deneyimleri edindiği aile ortamının sevgi dolu, olumlu ve tutarlı olmasına bağlıdır (Özyürek ve Tezel Şahin, 2012). Çocuğun sosyal yönden gelişmesi, ilerideki sosyal hayatını da etkilemektedir. Bu nedenle, erken çocukluk döneminde, çocukların sosyal yönden gelişmelerine de destek olan uygun bir ortam sunulmalıdır (Çağdaş ve Arı, 1999).

Çocukların doğdukları andan itibaren doğruları ve yanlışları ya da hangi davranışların kabul edilebilir olduğunu öğrenmelerinde destek gerekmektedir. Gelişimsel açıdan önemli bir dönem olarak kabul edilen okul öncesi yıllarda ahlaki ve sosyal kural bilgilerinin de kazandırılması gerekmektedir. Okul öncesi dönem çocukların ahlaki ve sosyal kural bilgi düzeyleri arasındaki anlamlı bir fark olup olmadığının belirlenmesi erken yıllarda çocukların ahlaki ve sosyal kuralara ilişkin bilgileri kazanmalarında rehberlik etmesi açısından önem taşımaktadır. Alan yazında, ahlaki ve sosyal gelişime yönelik çeşitli çalışmalara rastlamak mümkündür. Smetana (1981) okulöncesi ortamda oluşan ahlaki ve sosyal kural ihlaliyle ilgili çocukların düşüncelerini incelediği çalışmasında bu çocukların ahlaki kuralları sosyal kurallara göre genellenebilir, daha ciddi ve daha fazla cezaya layık olarak gördüklerini ortaya koymuştur. Ahlaki gelişim düzeyleri hakkında yapılan bazı çalışmalarda beden eğitimi dersinin çocuğun ahlak gelişimine etkisi (Güler, 2006), ailesiyle yaşayan ve çocuk yuvasındaki çocukların ahlaki ve sosyal kural anlayışları (Çeliköz ve ark. 2008), annelerin çocuklarıyla ilişkisi ve babaların tutumlarının, çocukların ahlâki ve sosyal kural bilgilerine etkisi (Özyürek ve Tezel Şahin, 2015), çocukların ahlaki gelişim düzeylerinin anne-babaların (Tezel Şahin ve Özyürek, 2010a) ve çocukların bazı kişisel özellikleri (Tezel Şahin ve Özyürek, 2010b) değişkenlerine göre incelendiği araştırmalar mevcuttur.Bu çalışmada, okul öncesi dönem 
çocukların ahlaki ve sosyal kural bilgi düzeylerinin incelenmesi amaçlanmıştır. Bu genel amaç doğrultusunda, aşağıdaki alt amaçlara cevap aranmıştır:

- Çocukların genel olarak ahlaki ve sosyal kural toplam puanı nedir?

- Okul öncesi dönem çocukların ahlaki ve sosyal kural bilgi düzeyleri; çocuğun cinsiyeti ve okula devam süresi ile annebabanın yaşı, öğrenim durumu ve mesleği bağımsız değişkenlerine göre farklılık göstermekte midir?

- Okul öncesi dönem çocukların ahlaki kural ve sosyal kural bilgi düzeyleri arasında anlamlı bir korelasyon var mıdır?

\section{Yöntem}

\section{Araştırma Modeli}

Nicel olarak tasarlanan bu araştırma, ilişkisel tarama modelinde yap1landırılmış betimsel bir çalışmadır (Büyüköztürk, 2008; Karasar, 2014).

\section{Çalışma Grubu}

Araştırmanın evreninde, Ordu İli Fatsa İlçe Milli Eğitim Müdürlüğüne bağlı 27 resmi okul öncesi eğitim kurumu ve bu kurumlara 2015-2016 eğitim öğretim yılında devam eden 60 ay ve üzeri yaş aralığında toplam 1060 çocuk bulunmaktadır. Bu okul öncesi eğitim kurumlarından rastgele 7 anasınıfı ve 3 bağımsız anaokulu olmak üzere toplam on okul seçilmiştir. Böylece evrene genelleme yapma imkânı olmuştur (Creswell, 2016). Çalışma grubunu, katılmaya gönüllü resmi anasınıfı ve anaokullarına devam eden 60 ay ve üzeri yaş aralığında 123'ü kız, 104'ü erkek olmak üzere 227 çocuk oluşturmuştur.

\section{Veri Toplama Araçları}

Araştırmada veri toplama aracı olarak çocuklar ve ailelere ait bazı kişisel bilgilerin sorgulandığı "Kişisel Bilgi Formu", çocukların ahlaki ve sosyal kural bilgilerinin değerlendirilmesinde Smetana (1981) tarafından 
geliştirilen, Seçer ve Sarı (2006) tarafından Türk kültürüne uygun bir biçimde yeniden düzenlenen "Ahlaki ve Sosyal Kural Algısı Ölçeği" (Preschool Children's Conceptions of Moral and Social Rules) ve çocukların bu ölçekteki olaylara bakış açılarını ifade etmek için yararlanılan yüz ifadeleri çizimleri kullanılmıştır. Çocukların Ahlaki ve Sosyal Kural Bilgilerini Değerlendirme Ölçeği kapsam ve görünüş geçerliği konusunda uzman görüşü alınmış, ön test-son test korelasyon katsayısı r=0,78 bulunmuştur (Seçer, Sarı ve Olcay, 2006; Çeliköz ve ark. 2008). Ölçekte toplam 10 resim bulunmaktadır.

\section{Ahlâki kurallar ile ilgili resimler;}

- Bir çocuk bir başka çocuğa vurmaktadır.

- Bir çocuk oyuncak ayısını arkadaşıyla paylaşmamaktadır.

- Bir çocuk başka bir çocuğu itmektedir.

- Bir çocuk başka bir çocuğa su atmaktadır.

- Bir çocuk, başka bir çocuğun elinde bulunan elmayı zorla almaktadır.

\section{Sosyal kurallarla ilgili resimler;}

- Bir çocuk arkadaşlarıyla oyuna katılmamaktadır.

- Bir çocuk okuldaki hikâye saatinde, oturması gereken yere oturmamaktadır.

- Bir çocuk, yediği elmanın çöpünü yere atmaktadır.

- Bir çocuk oyuncağını olması gereken yere koymamaktadır.

- Bir çocuk paltosunu askıya asmayıp yere atmaktadır.

Uygulamada, her resimde yaşanan olayı çocukların ne kadar algıladıklarını belirlemek amacıyla dört yüz ifadesi kullanılmıştır. İlk resimde, kabul eden ve onaylayan mutlu yüz ifadesi; ikinci resimde, biraz kızgın/onaylamayan yüz ifadesi; üçüncü resimde çok kızgın/hiç onaylamayan yüz ifadesi ve dördüncü resimde ise çok çok kıgın/kesinlikle onaylamayan yüz ifadesi yer almaktadır.

\section{Veri Toplama Yöntemi}

Ölçek çocuklara bireysel olarak uygulanmıştır. Uygulama, her çocukla ayrı ayrı olarak yaklaşık 20 dakika sürmüştür. Çocuklara çalışma hakkında kısa bir açıklama yapılmıştır. Öncelikle çocuklara dört farklı yüz ifadesinin ne anlama geldiği açıklanarak örnek bir uygulama 
yapılmıştır. Daha sonra çocuğa, ölçek resimleri gösterilmiş ve ilgili altı soru sorulmuş, çocukların cevapları kuramsal olayları kodlama cetveline kaydedilmiştir. Resimler gösterilirken çocuklara yöneltilen sorular, onların ahlaki ve sosyal kurallarla ilgili bilgilerini değerlendirme amacını taşımaktadır. Her çocuğa kendisine gösterilen resimdeki olay sence doğru mu? yanlış mı? diye sorulmuştur. Çocukların "doğru" cevabı 0 puan, "yanlış" cevabı ise 1 puan şeklinde kaydedilmiştir. "Eğer bu olay yanlışsa", sence ne kadar kötü? yüz ifadelerinden sana göre uygun olanı seçer misin?" diye sorulmuştur. Çocuk mutlu yüz ifadesini seçtiğinde 1 puan, biraz kızgın/onaylamayan yüz ifadesini seçtiğinde 2 puan, çok kızgın/hiç onaylamayan yüz ifadesini seçtiğinde 3 puan, çok çok kızgın/kesinlikle onaylamayan yüz ifadesini seçtiğinde ise 4 puan verilmiştir.

Çocuklara; "Resimdeki çocuğun yaptığını öğretmeni görmemiş olsaydı (ahlâki ve sosyal kurallarla ilgili otorite yokluğu), resimdeki olayla ilgili olarak önceden belirlenmiş bir kural olmasaydı (ahlâki ve sosyal kurallarla ilgili kural yokluğu), çocuk yaptığı davranışı başka bir yerde yapsaydı (ahlâki ve sosyal kurallarla ilgili genelleme algısı) doğru olur muydu?" soruları yöneltilmiştir. Çocuklardan gelen "evet" cevabı 0 puan, "hayır" cevabı ise 1 puan olarak kaydedilmiştir. Çocukların ahlâki ve sosyal kuralları çiğnemesi durumunda, ceza ile ilgili tutumunu ölçmek için; "Öğretmeni, bu resimdeki çocuğa ceza versin mi? Ne kadar ceza versin (az/çok)?" Sorusu sorulmuştur. "Hayır, ceza vermesin" cevabına 1 puan, "Evet, az ceza versin" cevabına 2 puan ve "evet, çok ceza versin" cevabına ise 3 puan verilmiştir. Bunun sonucunda ahlâki ve sosyal kurallarla ilgili ahlâki ve sosyal kural bilgisi toplam puanı elde edilmiştir. Alınan puanın yüksek olması, çocuğun ahlâki ve sosyal kural bilgisinin yüksek olduğu şeklinde yorumlanmıştır.

\section{Verilerin Analizi}

Araştırma verileri, SPSS 20 paket programı aracılığıyla çözümlenmiştir. Değişkenlerin normal dağılım gösterip göstermediğinin belirlenmesinde birim sayıları nedeniyle Shapiro Wilk's' değeri kullanılmıştır. Veri setinin normal dağılım göstermemesinden dolayı Mann Whitney $U$ ve Kruskal Wallis H Testlerinden yararlanılmıştır. 


\section{Bulgular}

Bu bölümde, alt problemlere göre bulgulara yer verilmiştir. Tablo 1'de tüm çocukların ahlaki ve sosyal kural toplam puanlarının dağılımı görülmektedir.

Tablo 1. Çocuklarn Ahlaki ve Sosyal Kural Bilgisi Puan Ortalamaları

\begin{tabular}{lccccc}
\hline & N & Minimum & Maximum & $\overline{\mathbf{X}}$ & SS \\
\hline Toplam Ahlaki Kural Bilgisi & 227 & 5,00 & 50,00 & 39,506 & 7,068 \\
\hline Toplam Sosyal Kural Bilgisi & 227 & 11,00 & 50,00 & 36,6960 & 7,889 \\
\hline
\end{tabular}

Tablo 1'e göre, çalışma grubunu oluşturan çocukların toplam Ahlaki Kural Bilgisi puanı $(\overline{\mathrm{X}}=39,51)$, Sosyal Kural Bilgisi puanından $(\overline{\mathrm{X}}=36,69)$ daha yüksektir. Buna göre, çocukların ahlaki kuralları sosyal kurallara göre daha fazla bildikleri söylenebilir.

Tablo 2' de çocukların Ahlaki Kural Bilgisi ve Sosyal Kural Bilgisi puanlarının cinsiyet değişkeninden etkilenip etkilenmediğine ilişkin bulgular verilmiştir.

Tablo 2. Ahlaki ve Sosyal Kural Bilgisi Puanlarmin Cinsiyete Göre Mann Whitney U-Testi Sonuçları.

\begin{tabular}{llrrrrrr}
\hline & \multirow{2}{*}{ Cinsiyet } & \multirow{N}{*}{} & $\overline{\mathbf{X}}$ & SS & \multicolumn{2}{c}{ Sira } & \multicolumn{2}{c}{ Mann Whitney U } \\
\cline { 8 - 9 } & & & & & Ort. & H & p \\
\hline Ahlak Kural & Kiz & 123 & 39,56 & 6,91 & 113,80 & & \\
Bilgisi & Erkek & 104 & 39,44 & 7,29 & 114,20 & & \multirow{2}{*}{0,961} \\
\hline Sosyal Kural & Kiz & 123 & 37,06 & 7,32 & 115,30 & & \\
Bilgisi & Erkek & 104 & 36,27 & 8,53 & 112,40 & $-0,332$ & 0,741 \\
\hline
\end{tabular}

Tablo 2'ye göre, çalışma grubunun Ahlaki Kural Bilgisi ve Sosyal Kural Bilgisi puanları ile cinsiyetleri arasında anlamlı farklılık bulunmamaktadır $(\mathrm{p}>0,05)$. Buna göre, çocukların, ahlaki kural bilgisi ve sosyal kural bilgisinin cinsiyet değişkenine göre farklılaşmadığı söylenebilir.

Tablo 3'te çocukların Ahlaki Kural Bilgisi ve Sosyal Kural Bilgisi puanlarının okula devam süresi değişkeninden etkilenip etkilenmediğine ilişkin bulgular verilmiştir. 
Tablo 3. Ahlaki ve Sosyal Kural Bilgisi Puanlarnın Okula Devam Süresine Göre Mann Whitney U-Testi Sonuçları

\begin{tabular}{|c|c|c|c|c|c|c|c|}
\hline & \multirow{2}{*}{$\begin{array}{l}\text { Okula } \\
\text { Devam } \\
\text { Süresi }\end{array}$} & \multirow[b]{2}{*}{$\mathbf{N}$} & \multirow[b]{2}{*}{$\bar{x}$} & \multirow[b]{2}{*}{ SS } & \multirow{2}{*}{$\begin{array}{l}\text { Sira } \\
\text { Ort. }\end{array}$} & \multicolumn{2}{|c|}{ Mann Whitney U } \\
\hline & & & & & & $\mathbf{H}$ & $\mathbf{p}$ \\
\hline Ahlak Kural & İlk yıl & 130 & 39,00 & 7,71 & 110,83 & \multirow{2}{*}{1,400} & \multirow{2}{*}{0,491} \\
\hline Bilgisi & 2. y1l & 97 & 40,18 & 5,72 & 120,84 & & \\
\hline Sosyal Kural & İlk yıl & 130 & 36,06 & 7,96 & 107,81 & \multirow{2}{*}{2,700} & \multirow{2}{*}{0,249} \\
\hline Bilgisi & 2. $\mathrm{yll}$ & 97 & 37,55 & 7,28 & 123,14 & & \\
\hline
\end{tabular}

Tablo 3'e göre, çalışma grubunun Ahlaki Kural Bilgisi ve Sosyal Kural Bilgisi puanlarıla okula devam süresi arasında anlamlı farklılık bulunmamaktadır $(\mathrm{p}>0,05)$. Buna göre, çocukların ahlaki kural bilgisi ve sosyal kural bilgisinin okula devam süresi değişkenine göre farklılaşmadığg söylenebilir.

Tablo 4'te çocukların Ahlaki Kural Bilgisi ve Sosyal Kural Bilgisi puanlarının anne ve baba yaşı değişkeninden etkilenip etkilenmediğine ilişkin bulgular verilmiştir.

Tablo 4'e göre, çalışma grubundaki çocukların anne ve babalarının yaşlarıyla çocukların Ahlaki Kural Bilgisi ve Sosyal Kural Bilgisi puanları arasında anlamlı bir fark bulunmamaktadır $(p>0,05)$. Buna göre, çocukların ahlaki ve sosyal kural bilgisinin anne ve baba yaşı değişkenine göre farklılaşmadığı söylenebilir.

Tablo 4. Ahlaki ve Sosyal Kural Bilgisi Puanlarının Anne ve Baba Yaşına Göre Kruskal Wallis H-Testi Sonuçları

\begin{tabular}{|c|c|c|c|c|c|c|c|c|}
\hline & & \multirow{2}{*}{ Yaş } & \multirow{2}{*}{$\mathbf{N}$} & \multirow{2}{*}{$\bar{X}$} & \multirow{2}{*}{ SS } & \multirow{2}{*}{$\begin{array}{l}\text { Sira } \\
\text { Ort. }\end{array}$} & \multicolumn{2}{|c|}{ Kruskal Wallis } \\
\hline & & & & & & & $\mathbf{H}$ & $\mathrm{p}$ \\
\hline \multirow{10}{*}{ 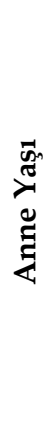 } & & 25 yaş ve altı & 13 & 43,31 & 3,04 & 148,80 & & \\
\hline & Ahlak & $26-30$ yaş & 57 & 39,95 & 5,66 & 112,90 & & \\
\hline & Kural & 31-35 yaş & 96 & 38,73 & 8,53 & 111,50 & 4,500 & 0,337 \\
\hline & Bilgisi & $36-40$ yaş & 50 & 39,16 & 6,36 & 108,40 & & \\
\hline & & 41 yaş ve üzeri & 11 & 41,09 & 4,39 & 125,90 & & \\
\hline & & 25 yaş ve altı & 13 & 41,54 & 4,16 & 157,60 & & \\
\hline & Sosyai & $26-30$ yaş & 57 & 37,54 & 6,92 & 116,90 & & \\
\hline & Kural & 31-35 yaş & 96 & 35,63 & 8,27 & 104,90 & 0,526 & 0,980 \\
\hline & & $36-40$ yaş & 50 & 36,54 & 8,61 & 117,30 & & \\
\hline & & 41 yaş ve üzeri & 11 & 36,64 & 7,68 & 111,80 & & \\
\hline
\end{tabular}




\begin{tabular}{|c|c|c|c|c|c|c|c|c|}
\hline \multirow{8}{*}{ 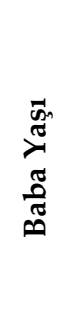 } & \multirow{4}{*}{$\begin{array}{c}\text { Ahlak } \\
\text { Kural } \\
\text { Bilgisi }\end{array}$} & 30 yaş ve altı & 24 & 40,42 & 8,10 & 127,81 & \multirow{4}{*}{3,100} & \multirow{4}{*}{0,365} \\
\hline & & 31-35 yaş & 83 & 39,92 & 7,14 & 117,86 & & \\
\hline & & $36-40$ yaş & 74 & 38,51 & 7,06 & 103,84 & & \\
\hline & & 41 yaş ve üzeri & 46 & 39,89 & 6,41 & 116,17 & & \\
\hline & Sosyal & 30 yaş ve altı & 24 & 38,42 & 8,61 & 132,94 & \multirow{4}{*}{4,900} & \multirow{4}{*}{0,179} \\
\hline & Kural & 31-35 yaş & 83 & 37,36 & 7,12 & 116,84 & & \\
\hline & \multirow[t]{2}{*}{ Bilgisi } & $36-40$ yaş & 74 & 35,26 & 8,19 & 101,86 & & \\
\hline & & 41 yaş ve üzeri & 46 & 36,91 & 8,22 & 118,51 & & \\
\hline
\end{tabular}

${ }^{*} \mathrm{p}<0,05$

Tablo 5'te çocukların Ahlaki Kural Bilgisi ve Sosyal Kural Bilgisi puanlarının anne ve baba öğrenim durumu değişkeninden etkilenip etkilenmediğine ilişkin bulgular verilmiştir.

Tablo 5. Ahlaki ve Sosyal Kural Bilgisi Puanlarnm Anne ve Baba Öğrenim Durumuna Göre Kruskal Wallis H-Testi Sonuçları

\begin{tabular}{|c|c|c|c|c|c|c|c|c|}
\hline & & \multirow{2}{*}{$\begin{array}{l}\text { Öğrenim } \\
\text { Durumu }\end{array}$} & \multirow{2}{*}{$\mathbf{N}$} & \multirow{2}{*}{$\bar{x}$} & \multirow{2}{*}{ SS } & \multirow{2}{*}{$\begin{array}{l}\text { Sira } \\
\text { Ort. }\end{array}$} & \multicolumn{2}{|c|}{ Kruskal Wallis } \\
\hline & & & & & & & $\mathrm{H}$ & p \\
\hline \multirow{8}{*}{ 吾 } & Ahlak & İlkokul & 72 & 38,38 & 7,86 & 103,95 & 6,115 & 0,106 \\
\hline & Kural & Ortaokul & 44 & 39,93 & 7,26 & 118,91 & & \\
\hline & Bilgisi & Lise & 60 & 38,98 & 6,69 & 107,63 & & \\
\hline & & Üniversite & 51 & 41,35 & 5,84 & 131,44 & & \\
\hline & Sosyal & İlkokul & 72 & 35,44 & 7,77 & 101,28 & \multirow{4}{*}{5,833} & \multirow{4}{*}{0,120} \\
\hline & Kural & Ortaokul & 44 & 37,59 & 7,78 & 120,33 & & \\
\hline & Bilgisi & Lise & 60 & 36,58 & 7,61 & 111,89 & & \\
\hline & & Üniversite & 51 & 37,82 & 8,64 & 128,97 & & \\
\hline \multirow{8}{*}{$\frac{\widetilde{0}}{5}$} & Ahlak & İlkokul & 50 & 37,64 & 8,05 & 96,18 & 5,371 & 0,194 \\
\hline & Kural & Ortaokul & 40 & 39,15 & 8,00 & 112,89 & & \\
\hline & Bilgisi & Lise & 79 & 40,09 & 6,30 & 118,80 & & \\
\hline & & Üniversite & 58 & 39,20 & 6,28 & 123,59 & & \\
\hline & Sosyal & İlkokul & 50 & 34,16 & 7,52 & 89,18 & \multirow{4}{*}{$\begin{array}{c}11,628 \\
\text { Anlaml1 } \\
\text { fark }\end{array}$} & \multirow{4}{*}{$\begin{array}{c}0,009^{*} \\
1-2,1-3, \\
1-4,2-4\end{array}$} \\
\hline & Kural & Ortaokul & 40 & 36,25 & 8,20 & 108,95 & & \\
\hline & Bilgisi & Lise & 79 & 37,47 & 7,55 & 120,51 & & \\
\hline & & Üniversite & 58 & 37,13 & 7,06 & 130,01 & & \\
\hline
\end{tabular}

${ }^{*} \mathrm{p}<0,05$

Tablo 5'e göre, çalışma grubundaki çocukların annelerinin öğrenim durumu ile çocukların Ahlak Kural Bilgisi ve Sosyal Kural Bilgisi puanları arasında anlamlı bir ilişki bulunmamaktadır ( $>>0,05)$. Buna göre, çocukların ahlaki ve sosyal kural bilgisinin anne öğrenim durumu değişkenine göre farklılaşmadı̆̆ı söylenebilir.

Baba öğrenim durumu ile çocukların Ahlak Kural Bilgisi arasında anlamlı bir ilişki bulunmazken ( $p>0,05)$ çocukların sosyal kural bilgisi pu- 
anları arasında anlamlı bir ilişki bulunmaktadır $(p<0,05)$. Sosyal Kural Bilgisi puanları ilkokul mezunu babaların diğer tüm gruplara göre anlamlı derecede düşük $(\bar{X}=34,16)$ olduğu görülmektedir. Üniversite mezunu babaların puanı ( $\overline{\mathrm{X}}=38,49)$, ortaokul mezunu babaların puanından $(\overline{\mathrm{X}}==36,25)$ anlamlı derecede yüksektir $(\mathrm{p}<0,05)$. Buna göre, babası ilkokul mezunu olan çocukların, babası daha yüksek öğrenim düzeyindeki çocuklara göre ve babası ortaokul mezunu olan çocukların babası üniversite mezunu olanlara göre sosyal kural bilgilerinin daha düşük düzeyde olduğu söylenebilir. Yani baba öğrenim düzeyinin yüksek olmasının çocukların sosyal kural bilgi düzeyini artırdığı söylenebilir.

Tablo 6' da Çocukların Ahlaki Kural Bilgisi ve Sosyal Kural Bilgisi puanlarının anne ve baba mesleği değişkeninden etkilenip etkilenmediğine ilişkin bulgular verilmiştir.

Tablo 6. Ahlaki ve Sosyal Kural Bilgisi Puanlarını Anne ve Baba Mesleğine Göre Kruskal Wallis H-Testi Sonuçları

\begin{tabular}{|c|c|c|c|c|c|c|c|c|}
\hline & & \multirow{2}{*}{ Meslek } & \multirow{2}{*}{$\mathbf{N}$} & \multirow{2}{*}{$\bar{x}$} & \multirow{2}{*}{ SS } & \multirow{2}{*}{$\begin{array}{l}\text { Sira } \\
\text { Ort. }\end{array}$} & \multicolumn{2}{|c|}{ Kruskal Wallis } \\
\hline & & & & & & & $\mathrm{H}$ & $\mathrm{p}$ \\
\hline \multirow{10}{*}{ 妾 } & \multirow{5}{*}{$\begin{array}{l}\text { Ahlak } \\
\text { Kural } \\
\text { Bilgisi }\end{array}$} & Çalışmıyor & 156 & 39,13 & 7,52 & 111,63 & \multirow{5}{*}{7,900} & \multirow{5}{*}{0,095} \\
\hline & & Serbest & 18 & 38,89 & 5,51 & 101,03 & & \\
\hline & & İşçi & 20 & 39,90 & 6,39 & 117,88 & & \\
\hline & & Memur & 10 & 38,20 & 5,45 & 91,30 & & \\
\hline & & $\begin{array}{l}\text { Profesyonel (dr, } \\
\text { avukat vb.) }\end{array}$ & 23 & 42,74 & 5,50 & 146,72 & & \\
\hline & \multirow{5}{*}{$\begin{array}{l}\text { Sosyal } \\
\text { Kural } \\
\text { Bilgisi }\end{array}$} & Çalışmıyor & 156 & 36,62 & 7,87 & 112,96 & \multirow{5}{*}{7,800} & \multirow{5}{*}{0,097} \\
\hline & & Serbest & 18 & 36,33 & 7,54 & 109,14 & & \\
\hline & & İşçi & 20 & 35,10 & 6,94 & 95,75 & & \\
\hline & & Memur & 10 & 34,70 & 9,78 & 100,25 & & \\
\hline & & $\begin{array}{l}\text { Profesyonel (dr, } \\
\text { avukat vb.) }\end{array}$ & 23 & 39,78 & 8,00 & 146,72 & & \\
\hline \multirow{8}{*}{ ڤ్ } & \multirow{4}{*}{$\begin{array}{l}\text { Ahlak } \\
\text { Kural } \\
\text { Bilgisi }\end{array}$} & Serbest & 108 & 39,10 & 7,22 & 109,19 & \multirow{4}{*}{5,400} & \multirow{4}{*}{0,146} \\
\hline & & İşçi & 75 & 38,77 & 7,55 & 108,99 & & \\
\hline & & Memur & 14 & 41,36 & 5,08 & 129,25 & & \\
\hline & & $\begin{array}{l}\text { Profesyonel (dr, } \\
\text { avukat vb.) }\end{array}$ & 30 & 41,93 & 5,51 & 136,72 & & \\
\hline & \multirow{4}{*}{$\begin{array}{c}\text { Sosyal } \\
\text { Kural } \\
\text { Bilgisi }\end{array}$} & Serbest & 108 & 35,93 & 8,24 & 107,76 & \multirow{4}{*}{$\begin{array}{c}14,400 \\
\text { Anlamlı } \\
\text { fark }\end{array}$} & \multirow{4}{*}{$\begin{array}{c}0,002^{*} \\
1-4 \\
2-4 \\
3-4\end{array}$} \\
\hline & & İşçi & 75 & 36,09 & 7,83 & 107,89 & & \\
\hline & & Memur & 14 & 35,86 & 8,18 & 104,11 & & \\
\hline & & $\begin{array}{l}\text { Profesyonel (dr, } \\
\text { avukat vb.) }\end{array}$ & 30 & 41,37 & 4,66 & 156,35 & & \\
\hline
\end{tabular}

${ }^{*} \mathrm{p}<0,05$ 
Tablo 6'ya göre, çalışma grubundaki çocuklarının annelerinin meslekleriyle çocukların Ahlak Kural Bilgisi ve Sosyal Kural Bilgisi puanları arasında anlamlı bir fark bulunmamaktadır $(\mathrm{p}>0,05)$. Buna göre, çocukların ahlaki ve sosyal kural bilgisinin anne mesleği değişkenine göre farklılaşmadığ 1 söylenebilir.

Babaların mesleği ile çocukların Ahlak Kural Bilgisi arasında anlamlı bir ilişki bulunmazken $(p>0,05)$ baba mesleği ile çocukların Sosyal Kural bilgisi puanları arasında anlamlı bir ilişki bulunmaktadır $(\mathrm{p}<0,05)$. Doktor, avukat, öğretmen gibi profesyonel meslek grubunda çalışan babaya sahip çocukların Sosyal Kural Bilgisi puanları $(\bar{X}=41,37)$ babası serbest meslek, işçi veya memur olan çocuklara göre anlamlı ölçüde daha yüksektir. Buna göre, babası profesyonel bir meslekte çalışan çocukların sosyal kural bilgilerinin diğerlerine göre daha iyi düzeyde olduğu söylenebilir.

Tablo 7'de Çocukların Ahlaki Kural Bilgisi Ölçek puanları ile Sosyal Kural Bilgisi Ölçek puanları arasındaki ilişkinin korelasyon katsayısı sonuçları verilmiştir.

Tablo 7. Ahlaki Kural Bilgisi Ölçek Puanları ile Sosyal Kural Bilgisi Ölçek Puanları Arasindaki Korelasyon

\begin{tabular}{lll}
\hline & \multicolumn{2}{l}{ Sosyal Kural Bilgisi } \\
\cline { 2 - 3 } & $\mathbf{r}$ & $\mathbf{p}$ \\
\hline Ahlaki Kural Bilgisi & 0,664 & $0,000^{*}$ \\
\hline
\end{tabular}

Tablo 7'ye göre, çocukların ahlaki kural bilgisi ile sosyal kural bilgisi arasında pozitif yönlü anlamlı bir ilişki vardır $(p<0,05)$. Buna göre çocukların ahlaki kural bilgisi arttıkça sosyal kural bilgilerinin de arttığı ya da ahlaki kural bilgisi azaldıkça sosyal kural bilgisinin de azaldığı söylenebilir. 


\section{Tartışma}

Çalışmada çocukların ahlaki kuralları sosyal kurallara göre daha fazla bildikleri saptanmıştır. Yau ve Smetana (2003), çalışmalarında çocukların ahlaki kural anlayışlarının, sosyal kural anlayışından daha erken bir zaman diliminde gelişmektedir sonucuna ulaşmışlardır.

Çalışmada çocukların cinsiyetlerinin, ahlaki ve sosyal kural bilgisi üzerine bir etkisi olmadığı saptanmıştır. Alan yazında bu bulguyu destekler çalışmalar mevcuttur (Smetana, 1981; Walker, 1984; Özgüleç, 2001; Seçer, Çağdaş ve Seçer, 2006; Tezel Şahin ve Özyürek, 2010b). Ahlaki ve sosyal kural bilgisinin cinsiyete göre değişmemesinin nedeni, okul öncesi dönemde cinsiyet farkı gözetilmeksizin genel kuralların öğretilmesinden kaynaklanıyor olabilir. Örneğin; bir başkasının saçını çekmek kız veya erkek olsun, her çocuğun yapmaması gereken bir davranış olarak görülmektedir.

Çalışmada çocukların okula devam süresinin ahlaki ve sosyal kural bilgisi üzerine bir etkisi olmadığı belirlenmiştir. Smetana (1981) tarafından yapılan çalışmada, okul öncesi öğrencilerinin ahlaki ve sosyal geleneksel değerler arasında ayrım yapabildikleri saptanmıştır. Çalışmada; okul öncesi çocukların, tüm ahlaki kural ihlallerini sosyal kuralların ihlalinden daha ciddi ve daha çok ceza gerektiren durumlar olarak tanımladıkları sonucuna ulaşılmıştır. Ahlaki değerlerin, kuralların bulunmadığı durumlarda yanlış olarak değerlendirilirken sosyal kuralların değerlendirilmemesine tesadüfî olarak yaklaşıldığı görülmüştür (Smetana,1981). Dinç (2002), çalışmasında okula devam süresinin çocuğun sosyal gelişim düzeyine etkisi olduğunu saptamıştır. Okul öncesi eğitimde ilk yılı olan çocuklarla kıyaslandığında, ikinci yılı olan çocukların sosyal gelişim düzeylerinin daha yüksek olduğunu saptamıştır. Yau ve Smetana (2003) anasınıfına devam eden çocuklarla yaptıkları çalışmada, çocukların ahlaki kuralları ihlali daha az tolere edilebilir, daha ciddi bulduklarını saptamışlardır. Seçer ve Sarı (2006), yapmış oldukları çalışmada okul öncesi eğitimin çocukların ahlaki ve sosyal kural bilgi farkındalık düzeyini olumlu yönde etkilediğini belirlemişlerdir. Tezel Şahin ve Özyürek (2010b), yapmış oldukları çalışmada altı yaşındaki çocukların okul öncesi eğitime devam süresinin ahlaki kural bilgisi üzerine etkisinin olduğunu belirlemişlerdir ve okul öncesi eğitime de- 
vam etme süresinin çocukların ahlaki ve sosyal kuralları içselleştirmede olumlu yönde etkisi olduğu sonucunu saptamışlardır. Bu bulgular, araştırma bulgularıyla farklılık göstermektedir ve daha önce yapılan çalışmalarla tutarlılık göstermemektedir.

Çalışmada, anne ve baba yaşılla çocukların ahlâki ve sosyal kural bilgisi arasında bir ilişki olmadığı belirlenmiştir. Tezel Şahin ve Özyürek (2010a) yaptıkları çalışmada anne yaşı ile çocukların ahlaki kural bilgisi arasında anlamlı bir ilişki olmadığını, fakat sosyal kural yokluğu arasında anlamlı bir ilişki olduğunu saptamışlardır, bu bulgular araştırma bulgularıyla farklılık göstermektedir. Bu çalışma bulgularına benzer olarak baba yaşı ile çocukların ahlâki ve sosyal kural bilgisi arasında anlamlı bir ilişki olmadığını saptamışlardır.

Çalışmada anne öğrenim durumunun çocukların ahlâki ve sosyal kural bilgisini etkilemediği saptanmıştır. Ayrıca çocukların ahlaki kural bilgisinin baba öğrenim durumu değişkenine göre farklılaşmadığı, fakat babası ilkokul mezunu olan çocukların, babası daha yüksek öğrenim düzeyindeki çocuklara göre ve babası ortaokul mezunu olan çocukların babası üniversite mezunu olanlara göre sosyal kural bilgilerinin daha düşük düzeyde olduğu saptanmıştır. Yani baba öğrenim düzeyinin yüksek olmasının çocukların sosyal kural bilgi düzeyini artırdığı belirlenmiştir. Çalışma bulgularıyla yakından ilişkili olarak Cabrera, Shannon and LeMonda (2007) çalışmalarında, öğrenim düzeylerinin en az lise mezunu olan babaların, erişilebilirlik, sorumluluk ve katılım yoluyla çocuklarına küçük şekillerde çok yönlü olarak katıldıklarını göstermişlerdir. Babanın katılımının kalitesi veya baba-çocuk etkileşimi olumlu ve destekleyici olmaktadır. Olumlu baba-çocuk etkileşimleri, çocuk gelişimi için önemlidir; gelişimde farklı alanlarda ortaya çıkan farklı etkiler vardır ve bu olumlu baba-çocuk etkileşimleri anne babalık ilişkisini ve ailenin insani ve mali değerlerini olumlu yönde desteklediğini saptamışlardır. Özyürek ve Tezel Şahin (2015) çalışmalarında, baba tutumlarının çocukların sosyal kural anlayışları üzerinde etkili olduğunu saptamışlardır. Babaların çocuklarıyla ilişkilerinde demokratik tutum ve sosyal değerlere uygun davranışlar sergilemesi durumunda, çocukların sosyal kural bilgisi ve anlayışlarının, buna bağlı olarak da sosyal davranışlarının olumlu yönde gelişeceği çıkarımında bulunulabileceği vurgulanmıştır. Telli (2015) yapmış olduğu çalışmada 
üniversite mezunu olan babaların babalık rolü algısının ilkokul, ortaokul ve lise mezunu olan babalara göre daha yüksek olduğunu saptamıştır. Kuruçırak (2010) çalışmasında, babalık rolü algısı ve eğitim düzeyi arasında anlamlı bir fark olduğunu saptamıştır. Üniversite mezunu babaların babalık rolüne ilişkin daha fazla olumlu algılara sahip olduğu görülmektedir. Çalışmanın bulgularından farklı olarak Koçak ve Tepeli (2006) yapmış oldukları çalışmada, dört, beş ve altı yaş grubu çocukların işbirliği ve sosyal ilişki davranışlarında anne öğrenim düzeyinin etkili olduğunu, baba öğrenim düzeyinin ise etkili olmadığını belirlemişlerdir. Yine Tezel Şahin ve Özyürek (2010a) çalışmalarında, anne-baba öğrenim durumunun çocukların ahlaki ve sosyal kural bilgisi üzerine etkisi olmadığını ve genel anlamda anne-babanın yaşı, öğrenim durumu ve meslekleri ile çocukların ahlaki ve sosyal kural anlayışları arasında anlamlı bir fark olmadığını saptamışlardır.

Bu bulgulardan yola çıkılarak çocukların ahlaki ve sosyal kural bilgileri üzerinde babaların önemli bir etkisi olduğu söylenebilir. Babaların öğrenim durumunun yüksek olmasıyla bağlantılı olarak profesyonel meslekte çalışma durumlarının ilişkili olduğu düşünülebilir. Babaerkil toplumlarda ve babanın otoriter olduğu ailede, babanın özellikle kural koyma ve kuralların öğrenilmesi konusunda etkili olduğundan hareketle babaların desteklenmesi önemli olabilir.

Çalışmada anne mesleğiyle çocukların ahlâki ve sosyal kural bilgisi arasında anlamlı bir ilişki olmadığı saptanmıştır. Ayrıca çalışmada, babası profesyonel bir meslekte çalışan çocukların sosyal kural bilgilerinin diğerlerine göre daha iyi düzeyde olduğu saptanmıştır. Smetana ve arkadaşları (1993), çocuğun sosyal kurallarla ilgili anlayışının, içinde bulunduğu sosyal sistemin kurallarını ve uygulamalarını yaşaması ile geliştiğini ileri sürmüşlerdir. Çocukların sosyal kuralları kavrayış biçimleri, otoriteden ve yetişkinlerden etkilenmektedir. Küçük çocuklar eğitimli ve başarılı ebeveynleri daha çok dikkate almakta, yetersiz ebeveynleri umursamamaktadır. Daha büyük çocuklar için ise kuralları yargılama kesinlikle sosyal statüye dayanmaktadır (Baç Uslu, 2005; Nobes ve Pawson, 2003). Bu bulgu ile benzer olarak, Tezel Şahin ve Özyürek (2010a) çalışmalarında, babası serbest meslekte çalışan çocuklarla kıyaslandığında, babası profesyonel bir mesleğe sahip olan çocukların, sosyal kuralları daha fazla içselleştirdikleri sonucuna varmışlardır. 
Çocukların ahlaki kural bilgisi arttıkça sosyal kural bilgilerinin de arttığı ya da ahlaki kural bilgisi azaldıkça sosyal kural bilgisinin de azaldığ belirlenmiştir. Çocuklar, günlük hayatta uyması gereken kuralları, öncelikle anne-baba ve ailedeki diğer bireylerle etkileşimleri sırasında öğrenmektedirler. İlerleyen dönemlerde, okul ortamında öğretmenler, akranlar ve diğer sosyal alanlar, çocukların kural anla- yışlarını etkilemektedir (Smetana, 1999; Seçer ve ark. 2006; Çeliköz ve ark. 2008; Berry ve O'Connor, 2010). Çeliköz ve ark. (2008) çalışma- larında, ailesi yanında kalan çocukların çocuk yuvasında kalan akran- larına göre ahlaki ve sosyal kuralları daha fazla önemsedikleri ve ahlaki kuralları genellenebilir ve otorite veya kuraldan bağımsız olarak gördük- lerini saptamışlardır.

\section{Sonuç ve Öneriler}

Çocukların ahlaki kuralları sosyal kurallara göre daha fazla bilmeleri, çocukların ahlaki kural anlayışlarının, sosyal kural anlayışlarından daha erken yaşta gelişmeye başladığı söylenebilir. Yani ahlaki kural anlayışları, sosyal kural anlayışından daha erken bir zaman diliminde gelişmektedir.

Okul öncesi çocukların ahlaki kural bilgisi, çocuk veya anne-babaya ait değişkenlerden etkilenmezken sosyal kural bilgileri, çocukların babalarının öğrenim durumu ve mesleği değişkenlerinden etkilenebilmektedir. Babaları üniversite mezunu ve profesyonel bir meslek grubunda çalışan çocukların, sosyal kural bilgileri diğerlerine göre daha iyi düzeydedir. Okul öncesi çocukların ahlaki kural bilgi düzeyleri arttıkça sosyal kural bilgi düzeyleri de artmakta veya ahlaki kural bilgi düzeyleri azaldıkça sosyal kural bilgi düzeyleri de azalmaktadır.

Çocuklar ahlaki ve sosyal kuralları doğdukları andan itibaren, yaşantılar yoluyla öğrenmektedirler. Çocuklar başta anne-babalarını, yakın çevrelerini ve içinde bulundukları sosyal çevreyi gözlemleyerek ahlaki ve sosyal kuralları öğrenebilmektedirler. Çocukların erken yaştan itibaren ahlaki ve sosyal kuralları içselleştirmeleri için anne-babaöğretmen başta olmak üzere çevresindeki yetişkinlerin olumlu rol model olmaları önemlidir. Özellikle baba karakterinin etkisi düşünüldüğünde, babaların çocuk gelişimi ve yetiştirilmesi konusunda daha aktif rol al- 
ması gerektiği söylenebilir. Bu nedenle, aile eğitimi çalışmalarına baba katılımının sağlanması önemli bir etki oluşturacaktır. Okul öncesi eğitimden itibaren, babaların çocukların eğitimlerinde aktif rol almalarını sağlayabilmek için babaların katılımını sağlayıcı etkinliklere yer verilebilir.

Ayrıca okul ortaminda, kurallar konmalı ve bu kurallara uyma konusunda oyun ağırlıklı etkinlikler uygulanmalıdır. Bu çalışmada, okul öncesi dönem çocukların ahlaki ve sosyal kural bilgi düzeyleri incelenmiştir. Çalışma farklı değişkenlerin ele alındığı örneklem gruplarıyla ve farklı değerlendirme teknikleriyle yapılabilir. 
EXTENDED ABSTRACT

\title{
A Study on Pre-School Children's Knowledge of Moral and Social Rules
}

\author{
Ayșe Meriç/Arzu Özyürek \\ Ordu University/Karabük University
}

Introduction: One of the foundations of a society is the moral rules. Morality is all the rules and values that enable an individual to distinguish between right and wrong, andinstruct the individual to implementsocial duties and responsibilities. Moral development can be described as the changes in the perception of justice of the child, the cultural values of the society or group that the child belongs, the child's perceptions about right or wrong and the child's behavior aboutmoral rules. Social development, on the other hand, is an important process that haps the development of the self. Socialization is a process where the children are transformed into functional individuals as a result of the influences by the values, behaviors and culture of other members of the society and by adapting to the group that they are a member of. In brief, socialization can be defined as the conformist behavior based on social rules. The initial relationships that the children establish with their social environment are usually with their parents and other family members. Thus, the family is an important space where children experience their initial social experiences. Behavior in compliance with moral and social rules is acquiredvia the interaction with the immediate environment such as parents, siblings, or school during the development process. The socialized individual behaves in compliance with the social values and expectations and could balance her or his needs and desires and the demands and expectations of the society. Socially compatible children can develop more complex skills, exhibit more positive behavior, and establish more positive relationships with their parents. In this period, children develop their moral and social behaviortraits, while developing their cognitive and language skills concurrently. Since moral and social rules are a social issue, it is very important ininteractions with other individuals. It is ne- 
cessary to acquire moral and social rule knowledgeduring pre-school period, which is considered as an important developmental stage. From the moment they were born, children need support to learn the right and wrong or the acceptable mode of behavior.

Objective: It is important to determine whether there is a significant difference between the moral and social rule knowledge levels of preschool children in order to guide the children to acquire knowledge on moral and social rules at an early age. Thus, the present study aimed to examine the knowledge of preschool childrenon moral and social rulesbased onseveral variables.

Method: The present quantitativestudy is a descriptive study designed withthe relational screening model. The study group included 227 children, 60 months old or older, attending public kindergartens, 123 of whom were female and 104 were male, and participated in the study on a voluntary basis. A "Personal Information Form" that included demographic information about the children and their parents,"Preschool Children's Conceptions of Moral and Social Rules" scale that aims to analyze the moral and social rule knowledge of the children and developed by Smetana (1981) and adapted to Turkish culture by Seçer and Sar1 (2009), and facial expressions drawings, used to reflect the views of the children on the events were used as data collection instruments in the present study. The scale was applied individually to the children. The application took about 20 minutes for each child. The pictures on the scale were presented to the child and six related questions were asked and the children's answers were recorded on the theoretical events coding table. The obtained data were analyzed using a computer.

Findings: It was determined that children's knowledge on moral codes was higher when compared totheir knowledge on social rules. It was also observed that the knowledge of the children on moral and social rules did not differ based on the gender variable, and the social rule knowledge of the children whose father was a university graduate and worked in a professional occupation had higher knowledge on social ruleswhen compared to others. There was a positive correlation between 
knowledge levels of pre-school children on moral and social rules. It was observed that as the knowledge levels of pre-school children on moral rules increased, their knowledge levels on social rules increased as well. Children learn about moral and social rules since birthvia experiences.

Conclusion and Recommendations: Children learn moral and social rules by observing their parents, their immediate surroundings and the social environment that they live in. For internalization of moral and social rules from early childhood, it is important that adults close to the children, especially parents and teachers, should provide positive role models. Particularly when the impact of the paternal character is considered, it can be argued that fathers should take on a more active role in child development and education of their children. Thus, father's participation in family education studieswould have an important impact. Furthermore, rules should be enforced, and game-intensive activities should be applied to facilitate the compliance to these rulesin the school environment.

\section{Kaynakça / References}

Ağır, M. (2014). Sosyal öğrenme kuramı. B. Aydın. (Ed.), Eğitim psikolojisi (gelişim ve öğrenme)(3. baskı) içinde (ss. 229-257). Ankara: Nobel Akademik Yayıncılık.

Akman, B. (1994). Okul öncesi dönemde ahlak (moral) gelişimi. Ş. Bilir. (Ed.), Okul öncesi eğitimcileri için el kitabı içinde (ss. 10-15). İstanul: Ya-Pa Yayınları.

Aral, N. ve Durualp E. (2011). Oyun temelli sosyal beceri eğitimi. Ankara: Vize Yayıncilık.

Aral, N., Gürsoy, F. ve Köksal A. (2001). Okul öncesi eğitimde oyun. İstanbul: Ya-Pa Yayınları.

Atay, M. (2011). Erken çocukluk döneminde gelişim-2. Ankara: Kök Yayıncilik.

Aydın, A. (2014). Eğitim psikolojisi gelişim-öğrenme-öğretim (13. baskı). Ankara: Pegem Akademi Yayıncılık. 
Aydın, M. Z. (2011). Okulda ahlak eğitimi ve ahlak öğretiminde örnek olay incelemesi yöntemi (4. baskı). Ankara: Nobel Akademik Yayıncılık .

Baç Uslu, B. (2005). Alt sosyo-kültürel özellikler, annenin eğitim durumu, kardeş sayısı ve cinsiyetin çocukların ahlak ve sosyal bilgilerine etkisinin incelenmesi. (Yayınlanmamış yüksek lisans tezi). Selçuk Üniversitesi, Konya.

Bedard, K. ve Dhuey, E. (2006). The persistence of early childhood maturity: international evidence of long-run age effects. The Quarterly Journal of Economics, 121(4), 1437-1472.

Bee, H. ve Boyd, D. (2009). Çocuk gelişim psikolojisi. O. Gündüz. (Çev.). İstanbul: Kaknüs Yayınlar.

Berry, D. ve O'Connor, E. (2010). Behavioral risk, teacher-child relationships and social skill development across middle childhood: A child-by-environment analysis of change. Journal of Applied Developmental Psychology, 31(1), 1-14.

Büyüköztürk, Ş. (2008). Sosyal bilimler için veri analizi el kitabı (9. baskı). Ankara: Pegem Akademi Yayıncılık.

Cabrera, N.J., Shannon, J D. ve LeMonda, C.T. (2007). Fathers' influence on their children's cognitive and emotional development: From toddlers to pre-k, Applied Development Science, 11(4), 208-213.

Can, G. (2015). Kişilik gelişimi.B. Yeşilyaprak. (Ed.), Eğitim psikolojisi gelişim-öğrenme-öğretim (14. baskı) içinde (ss. 125-163). Ankara: Pegem Akademi Yayıncilık.

Cora-Waters, A. C. (2004). Exploring the effects of teaching the character trait of respect to students in grades 4 and the impact it has on behavior during recess. (Masters thesis) Theses and Dissertations. 1131. http://rdw.rowan.edu/etd/1131

Creswell, J. W. (2016) Research design qualitative, qantitative and mixed methods approaches (4. baskıdan çeviri). S.B. Demir. (Çev. Ed.). Ankara: Eğiten Kitap.

Çağdaş, A. ve Arı, R. (1999). "Anne-çocuk iletişim dili eğitim"inin 4-5 yaş çocuklarının sosyal gelişimine olan etkileri. Selçuk Üniversitesi Sosyal Bilimler Enstitüsü Dergisi, 5, 391- 408.

Çam, Z., Çavdar, D., Seydooğulları, S. ve Çok, F. (2012). Ahlak gelişimine klasik ve yeni kuramsal yaklaşımlar, Kuram ve Uygulamada Eğitim Bilimleri Dergisi,12(2), 1211-1225. 
Çeliköz, N., Seçer, Z., Çetin, Ş. ve Demir Şen, H. Ş. (2008). Çocuk yuvası ve ailesiyle yaşayan çocukların ahlâki ve sosyal kural anlayışlarının karşılaştırmalı olarak incelenmesi. Gazi Üniversitesi Endüstriyel Sanatlar Ĕ̆itim Fakültesi Dergisi, 23,1-13.

Çiftçi, Arıdağ, N. (2015). Ahlâk gelişimi. A.Kaya. (Ed.) Ĕ̆gitim Psikolojisi içinden (ss. 149-191). Ankara: Pegem Akademi Yayıncılık.

Çiftçi, N. (2003). Kohlberg'in bilişsel ahlak gelişimi teorisi: Ahlak ve demokrasi eğitimi. Değerler Eğitimi Dergisi, 1(1), 43-77.

Danovitch, J.H. ve Keil, F.C. (2007). Choosing between hearts and minds: Children's understanding of moral advisors, Cognitive Development, 22, 110-123.

Dinç, B. (2002). Okulöncesi eğitimin 4-5 yaş çocuğunun sosyal gelişimine etkileri konusunda öğretmen görüşleri. (Yayımlanmamış yüksek lisans tezi). Anadolu Üniversitesi, Eskişehir.

Gander, M.J. ve Gardiner, H.W. (2007). Çocuk ve ergen gelişimi (6. baskı). B. Onur. (Çev Ed.). Ankara: İmge Kitapevi Yayıncılık.

Geçtan,E.(1999). İnsan olmak. (20. Baskı), İstanbul: Remzi Kitabevi.

Giren, Y.S. (2008). Kendini kontrol eğitiminin okulöncesi çocukların ahlaki ve sosyal kural algzlarn ile bilişsel tempolarna etkisinin incelenmesi. (Yayımlanmamış yüksek lisans tezi). Selçuk Üniversitesi, Konya.

Girgin, A., Kurnaz A. \& Zobu O. (2011). “Erken çocukluk eğitimi ve aile eğitiminin önemi", I. Türkiye Çocuk Hakları Kongresi Yetişkin Bildirileri Kitabı-1, (ss. 66-74). İstanbul: Çocuk Vakf1 Yayınları.

Güler, E. D. (2006). Ortaöğretim kurumlarında beden eğitimi dersinin çocuğun ahlak gelişimine etkisi. (Yayımlanmamış yüksek lisans tezi). Selçuk Üniversitesi, Konya.

Güler, S. (2015). Sosyal oyunun 48-69 aylık çocukların ahlaki ve sosyal kural algılarına etkisinin incelenmesi. (Yayımlanmamış yüksek lisans tezi). Gazi Üniversitesi, Ankara.

Günindi, Y. (2010). Anasınıfina devam eden altı yaş çocuklarına uygulanan sosyal uyum beceri eğitimi programının çocukların sosyal uyum becerilerinin gelişimine etkisi. (Yayımlanmamış yüksek lisans tezi). Gazi Üniversitesi, Ankara. 
Günindi,N. ve Kandır, A. (2012).Okul öncesi eğitim kurumlarına devam eden altı yaş çocuklarının sosyal uyum becerileri ile anne-babalarının empatik becerileri arasındaki ilişkinin incelenmesi. IIB International Refereed Academic Social Sciences Journal, 3(5), 35-46.

Hatunoğlu, A., Halmatov, M. ve Hatunoğlu, B.Y. (2012). Ailelerin sosyoekonomik düzeylerine göre okul öncesi dönemdeki çocukların ahlaki ve sosyal kural bilgilerinin incelenmesi. Akademik Bakış Dergisi, 32, 1-15.

Kağıtcıbaşı, Ç. ve Cemalcılar, Z. (2014). Günümüzde insan ve insanlarsosyal psikolojiye giriş. (16. baskı), İstanbul: Evrim Yayınevi.

Karasar, N. (2014). Bilimsel araştırma yöntemi. (27. baskı).Ankara: Nobel Akademik Yayıncilik.

Koçak, N. ve Tepeli, K. (2006). Dört-beş yaş çocuklarında sosyal ilişkiler ve işbirliği davranışlarının çeşitli değişkenler açısından incelenmesi. I. Uluslararası Okulöncesi Eğitim Kongresi/1st International PreSchool Education Conference. II. Cilt, (ss: 9-22). İstanbul: Ya-Pa Yayınları.

Kuruçırak, Ş. (2010). 4-12 aylık bebeği olan babaların, babalık rolü algısı ile bebek bakımına katılımı arasındaki ilişki. (Yayınlanmamış yüksek lisans tezi). Akdeniz Üniversitesi, Antalya.

Nisan, M. ve Kohlberg, L. (1982). Universality and variations in moral judgment: a longitudinal and cross-sectional study in Turkey. Child Development,53(4), 865-876.

Nobes, G. ve Pawson, C. (2003). Children's understanding of social rules and social status. Merrill-Palmer Quarterly,49(1), 77-99.

Özgüleç, F. (2001). 7-11 yaşlarındaki çocukların ahlaki yargılarının gelişimi. (Yayımlanmamış yüksek lisans tezi). Ankara Üniversitesi, Ankara.

Orçan, M. (2012). Sosyal gelişim. E. Deniz (Ed.), Erken Çocukluk Döneminde Gelişim, (4. baskı) içinde (ss. 127-181). Ankara: Maya Akademi.

Özgün, Ö. (2012). Ahlak gelişimi. E. Deniz (Ed.), Erken Çocukluk Döneminde Gelişim, (4.baskı) içinde (ss. 267-285). Ankara: Maya Akademi. 
Özyürek, A. ve Tezel Şahin, F. (2012). Altı yaşında çocuğa sahip annelerin çocukları ile ilişkilerinin incelenmesi. IIB International Refereed Academic Social Sciences Journal,3(5), 72-86.

Özyürek, A. ve Tezel Şahin, F. (2015). Anne-çocuk ilişkisinin ve baba tutumlarının, çocukların ahlâki ve sosyal kural anlayışları üzerine etkisi. Eğitim ve Bilim Dergisi,40(177), 161-174.

San Bayhan, P. ve Artan, İ. ( 2007). Çocuk gelişimi ve eğitimi, İstanbul: Morpa Kültür Yayınları.

Sarıçam, H. ve Halmatov, M. (2012).Okul Öncesi Eğitime Devam Eden ve Etmeyen 6 Yaş Çocukların Ahlaki ve Sosyal Kural Algılamalarının Karşılaştırılması. Akademik Bakış Dergisi, 33, 1-14.

Seçer, Z. ve Sarı, H. (2006). Okul öncesi eğitim kurumuna devam eden ve etmeyen çocukların ahlaki ve sosyal kural bilgilerinin çeşitli değişkenler açısından karşılaştırmalı olarak analizi. Milli Eğitim Dergisi,172, 126-142.

Seçer, Z., Çağdaş, A. ve Seçer, F. (2006). Çocukların okul ortamındaki ahlaki ve sosyal kuralları ayırtetme becerisinin çeşitli değişkenler açısından incelenmesi. Pamukkale Üniversitesi Eğitim Fakültesi Dergisi, 20, 69-81.

Seçer, Z., Sarı, H. ve Olcay O. (2006). Anne tutumlarına göre okulöncesi dönemdeki çocukların ahlaki ve sosyal kural bilgilerinin incelenmesi. Selçuk Üniversitesi Sosyal Bilimler Enstitüsü Dergisi,16, 539-557.

Sheridan, S.M., Knoche, L.L., Edwards, C.P., Bovaird, J.A. ve Kupzyk K.A. (2010). Parent engagement and school readiness: Effects of the getting ready intervention on preschool children's socialemotional competencies.Early Education and Development, 21(1), 125-156.

Smetana, J.G. (1981). Preschool children's conceptions of moral and social rules. Child Development, 52, 1333-1336.

Smetana, J.G. (1989). Adolescents' and parents' reasoning about actual family conflict. Child Development, 60, 1052-1067.

Smetana, J.G., Schlagman, N. ve Adams, P. W. (1993). Preschool children's judgments about hypothetical and actual transgressions. Child Development, 64(1), 202-214. 
Smetana J.G. (1999). The role of parents in moral development: A social domain analysis. Journal of Moral Education,28(3), 311-321.

Smetana, J.G. (2006). Social-cognitive domain theory: Consistencies and variations in children's moral and social judgments. M. Killen ve J.G. Smetana (Ed.), Handbook of Moral Development içinde (ss.119153). New York, NY: Psychology Press.

TDK. (2016). Genel Türkçe Sözlük. Türk Dil Kurumu. http://www.tdk.gov.tr/ (Erişim tarihi: 10 Eylül 2016).

Telli, A. A. (2014). 3-6 yaş grubu çocuğu olan babaların babalık rolü algısı ve etkileyen faktörlerin belirlenmesi. (Yayımlanmamış yüksek lisans tezi). Atatürk Üniversitesi, Erzurum.

Tezel Şahin, F. Ve Özyürek, A. (2010a). Okul öncesi dönem çocuğa sahip ailelerin çocuklarının ahlaki ve sosyal kural anlayışları üzerine etkisi. Türkiye Sosyal Araştırma Dergisi,14(3), 75-90.

Tezel Şahin, F. ve Özyürek, A. (2010b). Okul öncesi eğitim kurumuna devam eden altı yaş çocuklarının ahlaki ve sosyal kural bilgilerinin incelenmesi. II. Uluslararası Türkiye Ĕ̆itim Araştırmaları Kongresi, 869-882.

Topbaşı, F. (2006). Okul öncesi dönem 6 yaş grubu çocukların törel (ahlâki) gelişiminde dramanın yeri ve önemi. (Yayımlanmamış yüksek lisans tezi). Ankara Üniversitesi, Ankara.

Turiel, E. (2002). The culture of morality: Social development, context, and conflict. Cambridge: University Press.

Tuzcuoğlu, S. (2014). Kişilik gelişimi. B. Aydın. (Ed.), Eğitim psikolojisi (gelişim ve öğrenme)(3. baskı) içinde (ss. 123-155). Ankara: Nobel Akademik Yayıncilık.

Uyanık Balat, G. (2005). Değerler ve değerler eğitim programları. A. Oktay ve Ö. P. Unutkan (Ed.), Okul Öncesi Eğitimde Güncel Konular içinde (ss. 197-212). İstanbul: Morpa Kültür Yayınları.

Uyanık Balat, G. ve Balaban Dağal, A. (2009). Okul öncesi eğitimde değerler eğitimi etkinlikleri (2.baskı). Ankara: Kök Yayıncılık.

Uzamaz, F. (2000). Ergenlerde sosyal beceriler ve değerlendirme yöntemleri. Çukurova Üniversitesi Sosyal Bilimler Enstitüsü Dergisi.6(6), 4958.

Walker, L.J. (1984). Sex differences in the development of moral reasoning: A critical review. Child Development, 55, 677-691. 
Yapıcı, Ş. ve Yapıcı, M. (2010). Eğitim psikolojisi (2. baskı). Ankara: Anı Yayıncilik.

Yapıc1, M. ve Yapıcı, Ş. (2005). Çocukta ahlaki gelişim. Bilim, Eğitim ve Düşünce Dergisi,5(3). (http://www.universitetoplum.org/text.php3?id=243/ Erişim tarihi: 19. 07. 2016).

Yau, J. ve Smetana, G. (2003). Conceptions of moral, social-conventional and personal events among chinese preschoolers in hong kong. Child Development,74(3), 647-658.

Yavuzer, H. (2009). Çocuk ve suç (12. Baskı). İstanbul: Remzi Kitabevi.

Yavuzer, H (2012).Çocuk psikolojisi (34. Baskı). İstanbul: Remzi Kitabevi.

Yavuzer, H. (2015). Çocuğunuzun ilk altı yılı (33. Bask). İstanbul: Remzi Kitabevi.

Yurtsever Kılıçgün, M. ( 2016). Sosyal gelişim. Erken çocukluk döneminde gelişim, Ed.: Arslan E. (2. Baskı), Eğiten Kitap, Ankara.

\section{Kaynakça Bilgisi / Citation Information}

Meriç, A. ve Özyürek, A. (2018). Okul öncesi dönem çocukların ahlaki ve sosyal kural bilgilerinin incelenmesi. OPUS - Uluslararası Toplum Araştırmaları Dergisi, 8(14), 137-166. DOI: 10.26466/opus.378956 